\section{Effect of Resistant and Susceptible East European Pears on Development and Mortality of the Pear Psylla, Cacopsylla pyricola (Förster)}

\author{
Richard L. Bell ${ }^{1,2}$ \\ U.S. Department of Agriculture, Agricultural Research Service, Appalachian \\ Fruit Research Station, Kearneysville, WV 25430
}

Additional index words. Pyrus, Sorbopyrus, Hemiptera, Psyllidae, antibiosis, antixenosis, feeding

\begin{abstract}
Pear psyllids (Cacopsylla spp., Hemiptera: Psyllidae) are major pests of European pear (Pyrus communis L.) in North America and Europe. In breeding resistant cultivars, a thorough understanding of the nature of host resistance and susceptibility is essential for designing efficient and accurate methods to identify resistant host genotypes. A developmental assay was performed on six genotypes previously identified as highly resistant, moderately resistant, or susceptible to nymphal feeding. Plants were infested with first instars of Cacopsylla pyricola (Förster), and feeding, mortality, and larval stage were observed for 34 days. Host genotypes significantly differed in feeding antixenosis at day 1 after infestation. Differences in antibiosis were also evident, as mortality of nymphs was greater on the feeding-resistant genotypes. There were also differences in the total numbers of surviving psylla and those developing to adults. Survival was directly related to the feeding antixenosis. There were no significant differences among the feedingsusceptible and moderately resistant genotypes in population age structure, except at day 19, reflecting the advanced stage of the few nymphs that did survive. Early feeding antixenosis was associated with mortality, either through a lack of feeding stimulation, feeding inhibition, or because of a direct toxic effect of the resistant plant genotypes. The short-term feeding antixenosis assay is predictive of long-term mortality and, to a lesser extent, with delayed development. 'Bartlett' and the wild seedling Y-167 were confirmed as susceptible, 'Karamanlika' and NY10352 were confirmed as moderately resistant, and Bacui-1 and Bacui-2 were confirmed as highly resistant.
\end{abstract}

Pear psyllids (Cacopsylla spp., Hemiptera: Psyllidae) are major pests of European pear (Pyrus communis L.) in orchards in most temperate regions where the crop is grown (Berrada et al., 1995; Westigard et al., 1970). In North America, the only species present is Cacopsylla pyricola (Förster), whereas in Europe, Cacopsylla pyri (L.) and, in the more northern regions, Cacopsylla pyrisuga (Förster) are also major pest species. Both adults and nymphs feed primarily in the vascular tissue of the leaves, petioles, and succulent shoots. Prolonged feeding in the

Received for publication 25 Sept. 2014. Accepted for publication 13 Dec. 2014.

We acknowledge the contributions of L. Claire Stuart for performing the evaluations, the late Dr. R.C. Lamb, formerly of Cornell University, for providing NY10352, Cheryl Vann for assistance with computer graphics, and the anonymous reviewers for their useful comments.

Mention of trade names or commercial products in this publication is solely for the purpose of providing specific information and does not imply recommendation or endorsement by the U.S. Department of Agriculture. USDA is an equal opportunity provider and employer.

${ }^{1}$ Research Horticulturist.

${ }^{2}$ To whom reprint requests should be addressed; e-mail richard.bell@ars.usda.gov.

in reduced photosynthesis and marked fruit. The insect is also the vector of the pear decline phytoplasma (Hibino et al., 1971). Pear psylla have rapidly developed resistance to commonly used pesticides such as pyrethroids (Pree et al., 1990), azinphosmethyl, endosulfan, Perthane, and fenvalerate (Follet et al., 1985), and biological controls are not always sufficiently effective (Shaltiel and Coll, 2010).

Host resistance and pear psylla behavior have recently been reviewed by Bell and Puterka (2003) and Nin et al. (2012). The behavioral and physiological responses of arthropod pests to resistant host genotypes are termed modes of host plant resistance, as distinct from the underlying mechanisms of resistance. Major modes of host plant resistance are as follows: 1) antixenosis, which can be observed in terms of difficulty in orientation and reduced settling (i.e., host finding), adult and nymphal feeding, and oviposition; 2) antibiosis, which delays development, increases mortality, reduces fecundity, and reduces egg hatch; and 3) tolerance, or the ability to withstand infestation without damage. The combination of these effects determines the overall level of pest colonization and damage to the host plant.

Resistance within the genus Pyrus to pear psylla has been demonstrated in the East Asian pear species $P$. betulifolia Bunge, $P$. calleryana Decne., P. fauriei Schneid., P. ussuriensis Maxim., and $P$. $\times$ bretschneideri Rehd., in $P$. ussuriensis $\times P$. communis hybrids (Harris, 1973; Harris and Lamb, 1973; Pasqualini et al., 2006; Quamme, 1984), in P. pyrifolia (Burm.) Nakai $\times P$. communis hybrids (Braniste et al., 1994; Robert et al., 2004, 2005), and in a few genotypes of the European "snow pear," P. nivalis Jacq. (Quamme, 1984; Westigard et al., 1970). Cultivars within the European pear species, $P$. communis L. with moderate to high levels of resistance include the old Italian cultivars Spina Carpi (Quarta and Puggioni, 1985; Briolini et al., 1988), Doyenne du Poitiers, and D'Aoǔt Lamer (Robert et al., 2004, 2005), and 15 landrace cultivars from Eastern Europe (Bell, 1992, 2003; Bell and Stuart, 1990). Two wild pears of uncertain parentage were found in Israel to have reduced susceptibility to $C$. bidens (Šulc) (ShaltielHarpaz et al., 2014). A high level of nymphal feeding resistance has also been identified in $\times$ Sorbopyrus auricularis (Knoop) C. K. Schneid. (Bell, 1992; Bell and Stuart, 1990), an intergeneric hybrid of possible use as a rootstock for pear or as a parent for the development of a novel fruit type. These studies identified antibiosis and ovipositional and feeding antixenosis as modes of resistance.

Nymphal feeding antixenosis has been associated with increased mortality and delayed development of nymphs (Bell, 1991; Butt et al., 1989; Puterka, 1997) in a limited number of both $P$. communis- and $P$. ussuriensis-derived cultivars and breeders selections. The purpose of this study was to further characterize host resistance in additional germplasm of interest for breeding.

\section{Materials and Methods}

The plants assayed included genotypes identified as resistant or susceptible to feeding of Cacopsylla pyricola (Förster) nymphs and/or development in previous studies (Bell, 1992; Bell and Stuart, 1990; Butt et al., 1989) (Table 1). Resistant genotypes were the $\times$ Sorbopyrus auricularis accessions, Bacui-1 and Bacui-2, collected in Romania (van der Zwet et al., 1989). These genotypes had been erroneously identified in the original collection records as $P$. $\times$ nivalis or hybrids of P. Xnivalis and P. communis (Bell and Stuart, 1990; van der Zwet e al., 1989). Moderately resistant genotypes were the $P$. communis landrace cultivar Karamanlika (PI 502165), collected in Serbia (Bell and Stuart, 1990; van der Zwet et al., 1987) and NY10352, a $P$. ussuriensis $\times P$. communis $\mathrm{BC}_{1}$ hybrid (Bell and Stuart, 1990). Susceptible genotypes were 'Bartlett' and Y-167 (PI 506373), a wild seedling collected in Serbia (van der Zwet et al., 1987). Trees of these genotypes were budded in the greenhouse on 'Bartlett' seedling rootstock in $20.3 \mathrm{~cm}$ diameter pots containing a potting mix containing peat, 
Table 1. Feeding, survival, and developmental indices for pear psylla on the Pyrus genotypes.

\begin{tabular}{|c|c|c|c|c|c|c|c|}
\hline Genotype & $\begin{array}{l}\text { Percent feeding } \\
\text { on day } 1^{z}\end{array}$ & $\begin{array}{l}\text { Percent feeding } \\
\text { on day } 5^{z}\end{array}$ & $\begin{array}{c}\text { Percent live nymphs } \\
\text { on day } 1\end{array}$ & $\begin{array}{c}\text { Percent live psylla } \\
\text { on day } 34\end{array}$ & $\begin{array}{l}\text { Mean day } \\
\text { of all adults }\end{array}$ & $\begin{array}{c}\text { Mean } \\
\text { no. adults }\end{array}$ & $\begin{array}{l}\text { PASI }^{x} \text { on } \\
\text { day } 19\end{array}$ \\
\hline Bartlett & $92 \pm 8 \mathrm{a}^{\mathrm{w}}$ & $92 \pm 8 \mathrm{a}$ & $92 \pm 8 a$ & $52 \pm 6 a$ & $22.8 \pm 0.8^{v}$ & $9.00 \pm 0.90 \mathrm{a}$ & $4.9 \pm 0.6 \mathrm{ab}$ \\
\hline Y-167 & $53 \pm 7 b$ & $50 \pm 11 b$ & $68 \pm 9 \mathrm{ab}$ & $31 \pm 7 \mathrm{a}$ & $19.6 \pm 0.6$ & $6.25 \pm 1.50 \mathrm{a}$ & $5.8 \pm 0.1 \mathrm{a}$ \\
\hline Karamanlika & $24 \pm 4 c$ & $26 \pm 5 \mathrm{bcd}$ & $45 \pm 7 \mathrm{bc}$ & $8 \pm 1 b$ & $23.6 \pm 2.1$ & $1.75 \pm 0.75 b$ & $4.9 \pm 0.5 \mathrm{ab}$ \\
\hline NY10352 & $23 \pm 3 \mathrm{~cd}$ & $34 \pm 9 b c$ & $39 \pm 10 b c$ & $8 \pm 6 b$ & $23.4 \pm 3.0$ & $1.50 \pm 1.19 b$ & $4.4 \pm 0.3 b$ \\
\hline Bacui-1 & $3 \pm 3 d$ & - & $23 \pm 5 c$ & $0 \pm 0 b$ & - & $0.00 \pm 0.00 \mathrm{c}$ & - \\
\hline Bacui-2 & $3 \pm 1 \mathrm{~d}$ & $8 \pm 5 \mathrm{~cd}$ & $18 \pm 7 \mathrm{c}$ & $0 \pm 0 \mathrm{~b}$ & - & $0.00 \pm 0.00 \mathrm{c}$ & - \\
\hline
\end{tabular}

${ }^{\mathrm{z}}$ Number of nymphs feeding/20.

${ }^{y}$ Includes counts of both nymphs and cumulative adults.

xPASI is the population age structure index (Puterka, 1997).

${ }^{w}$ Mean \pm SE. Means followed by the same letter are not statistically different, according to Fisher's protected $t$ test at $P=0.05$ with Tukey's multiple comparison adjustment computed by SAS PROC MIXED (Littell et al.,1996).

"Data were not distributed normally. Analyses by nonparametric analysis of variance (SAS PROC NPAR1WAY) and the Cochran-Haenszel statistic 2 (SAS PROC FREQ) indicated statistically significant differences.

composted hardwood bark, sand, and perlite. The trees were fertilized weekly with a $10 \mathrm{~N}$ $10 \mathrm{P}-10 \mathrm{~K}$ liquid solution to maintain active growth.

The developmental assay used newly eclosed first instar nymphs from a laboratory colony maintained on 'Bartlett' seedling rootstock. All leaves below the top six young, but fully expanded, leaves on each plant were removed and a piece of two-sided adhesive tape was placed around the stem of the plant to trap any nymphs that might migrate down the stem. Ten nymphs were transferred using a single-hair brush from a colony plant to each of the top two leaves of one plant of each genotype, for a total of 20 nymphs per plant. The plants were then kept in a growth room at $25^{\circ} \mathrm{C} \pm 1{ }^{\circ} \mathrm{C}$ with a $16 / 8 \mathrm{~h}(\mathrm{~L} / \mathrm{D})$ photoperiod under cool-white fluorescent lamps. Relative humidity was not controlled. Beginning one day after infestation, the number of live nymphs and the number of actively feeding nymphs on each leaf were recorded. Active feeding was indicated by the presence of a honeydew droplet surrounding a nymph. One day was considered an adequate interval to observe nymphal feeding acceptance or deterrence based on results that indicated that nymphal feeding on both susceptible and resistant pear clones commenced within $6 \mathrm{~h}$ (Butt et al., 1988). The observations were repeated at intervals of 3 to $5 \mathrm{~d}$, recording the number of nymphs in each instar, as well as the number of adults. Counting and identification of instar was facilitated by using a headband mounted Magni-Focuser (BioQuip, Rancho Dominquez, CA). Descriptions of each instar (Singleton-Smith et al., 1978) and color photographs served as guides to identify specific instars. When the first fifth instar was observed, the plants were enclosed in individual plastic cylindrical cages with ventilation holes covered with a fine plastic mesh screening. Adults were removed from the plants on the day they were first observed. Observations of a genotype were discontinued when all of the psylla on that plant were dead or eclosed to adults. The experiment was performed four times with separate plants for each replicate. Thus, the experiment was a randomized complete block design.

Variables analyzed were the percentage of live nymphs on day 1 after infestation, the percentage of nymphs feeding on day 1 based on the initial 20 infested, the mean day of first occurrence of each instar, the duration of each instar, the mean day to adult eclosion, cumulative numbers of adult, and the percentage of live psylla, including adults, on day 34. Antibiosis was further analyzed by computing a population age structure index (PASI) (Puterka, 1997) as follows:

$$
\mathrm{PASI}=\frac{\sum \mathrm{pn}_{x} \mathrm{nw}_{y}}{100}
$$

in which the percentage of individuals (pn) of each of the six possible developmental stages $(x=1$ to 6 , where $1=$ first instar and $6=$ adult), was determined. The pn for each stage was then multiplied by the nymphal stage value $\left(n w_{y}\right.$, which were 1 to 6$)$, and these values summed and divided by 100 . Thus, a PASI of 0 would indicate no live individuals and a PASI of 6 would indicate all adults. Differences among genotypes for PASI on each day were analyzed by analysis of variance (ANOVA).

Data were first analyzed to determine whether the residuals met the assumptions underlying the ANOVA. Residuals were generated using SAS PROC MIXED (Littell et al., 1996; SAS Institute Inc., 2013) using a randomized complete block design and Type III sums of squares. Homogeneity of variances was tested by an examination of residual plots. Normality was tested using the Shaprio-Wilk test in SAS PROC UNIVARIATE and examination of box and normal probability plots. Correlation of mean and residuals was examined using a plot of residual vs. predicted values and tested by SAS PROC CORR option SPEARMAN. Type III sums of squares were computed. The residuals for the percentage of feeding on days 1 and $5 \mathrm{fit}$ normal distributions, but the variances were unequal and required arcsine transformation. Data percentage of live nymphs on day 1 , the percentage of all live psylla on day 34 , the mean cumulative number of adults, and the PASI on day 19 fit normal distributions, and therefore, untransformed data were analyzed. Residuals for the duration of the third, fourth, and fifth instars and the mean first day of adult eclosion were normally distributed. Analyses for these variables were performed using SAS PROC MIXED. Mean separation for this procedure is performed using the TukeyKramer honestly significant difference (HSD) method, which adjusts for multiple comparisons. Mean separation letters for main effects were assigned by the SAS macro PDMIX 800 (Saxton, 1998). Residuals for the mean day of adult eclosion for all adults were not normal, and were heteroscedastic, but standard transformations did not improve non-normality. In addition, residuals for the mean day of first occurrence of the second, third, and fourth instars, and the mean duration of the first and second instars were not normal and means were correlated with variances. Therefore, for these variables with non-normal distributions, nonparametric analyses using $\mathrm{CMH} 2$ test of SAS PROC FREQ and SAS PROC NPAR1WAY were used for the analysis (SAS Institute Inc., 2013).

\section{Results}

The genotypes differed in the feeding acceptance on day $1(\operatorname{Pr}>F<0.0001)$, with 'Bartlett' exhibiting 92\% feeding, followed by $\mathrm{Y}-167$ at $53 \%$ (Table 1). The two Bacui genotypes exhibited $3 \%$ feeding and the 'Karamanlika' and NY10352 had intermediate values. The genotypes also differed significantly in the percentage of live nymphs feeding on day $5(\operatorname{Pr}>F=0.04)$. Thereafter, there was no significant difference because of mortality of nonfeeding nymphs (data not shown).

Mortality and development of the pear psylla on each genotype is shown graphically in Fig. 1. The proportion of original nymphs alive on the plants one day after infestation varied significantly $(\operatorname{Pr}>F<0.0001)$ among the genotypes, with 'Bartlett' and Y-167 being the highest at 0.92 and 0.68 , respectively. At five days after infestation, no nymphs survived on Bacui-1 and only a mean of 1.5 survived on Bacui-2. There was no further mortality on 'Bartlett' over these four days, whereas there was some increased mortality on the remaining genotypes, even on Y-167 (53\%), which had previously been identified as susceptible to nymphal feeding. There were significant $(\operatorname{Pr}>F<0.0001)$ differences in the percentage of live psylla (nymphs plus adults) surviving at day 34 , with a maximum of $52 \%$ for 'Bartlett', $31 \%$ for Y $-167,9 \%$ for 'Karamanlika' and $10 \%$ for NY10352, and $0 \%$ for Bacui-1 and Bacui-2. There were no significant differences in the 
A.

\section{Bartlett}

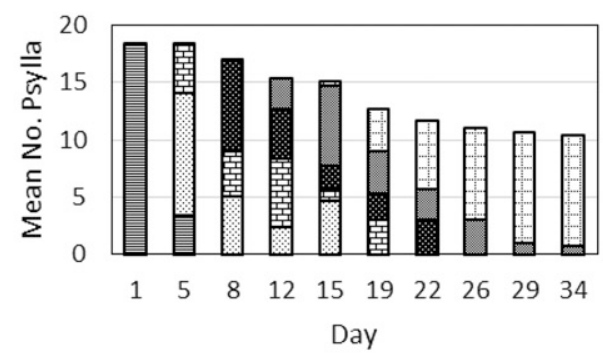

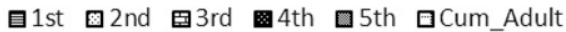

C.

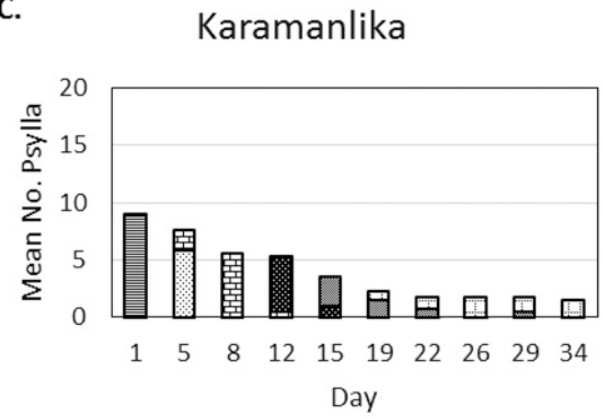

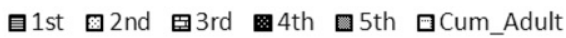

E.

\section{Bacui-1}

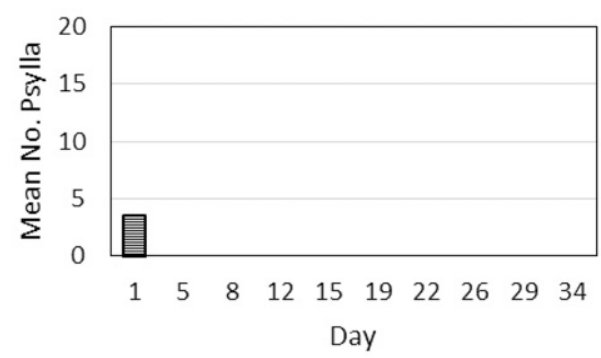

ㅂ1st 움2nd 回3rd 图4th 5th 口Cum_Adult
B.

P comm Y167

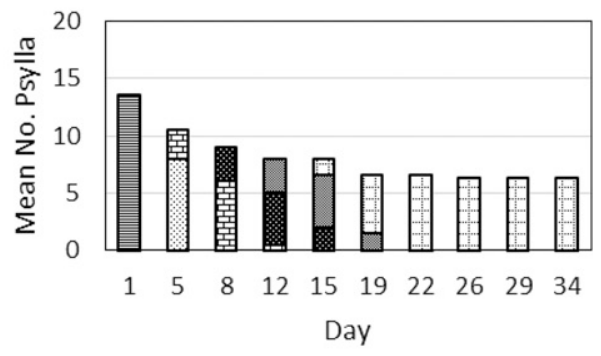

目1st 웅2nd 固3rd 圈4th 5th 口Cum_Adult

D.

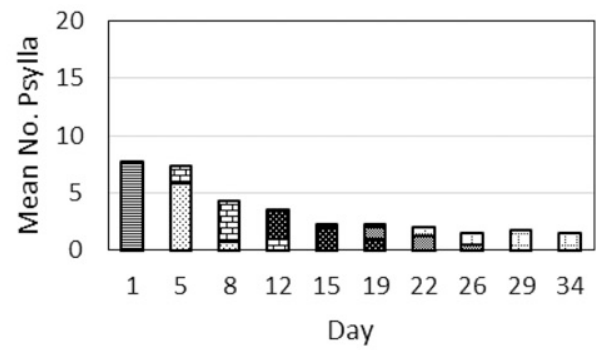

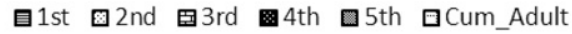

F.

Bacui-2

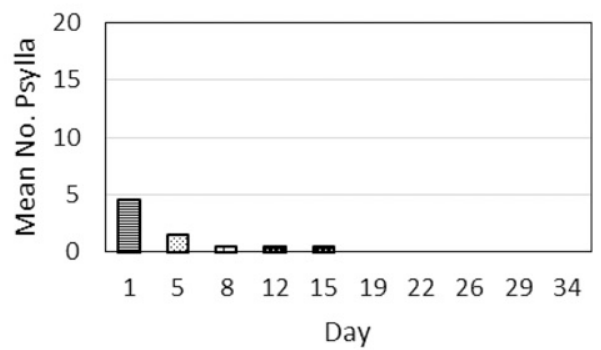

目1st 웅2nd 回3rd 웅 4th 5th 口Cum_Adult

Fig. 1. (A-F) Pear psylla survival and development on six pear host genotypes.

mean day of first adult eclosion, which varied from 17 to $24 \mathrm{~d}$ (Table 2). The mean day of eclosion for all adults varied from $\approx 19.6 \mathrm{~d}$ for Y-167 to $\approx 23.6 \mathrm{~d}$ for 'Karamanlika'. The nonparametric tests indicated significant differences (Cochran-Mantel-Haenszel statistic $2=0.04$; Kruskal-Wallis $\operatorname{Pr}>\chi^{2}=$ $0.03)$. There were significant $(\operatorname{Pr}>F<$ 0.0001 ) differences in the mean number of adults developing, with three groups, 'Bartlett' and Y-167 in the most susceptible group, 'Karamanlika' and NY10352 in the moderately resistant group, and Bacui-1 and Bacui- 2 in the highly resistant group.

The mean first days for each instar did not differ significantly, probably because of variability among the small number of replicates per genotype ( $n=3$ or 4 ) (Table 2; Fig. 1). This was especially evident for the second and third stadia (Table 2). No second instar nymphs developed on Bacui-1, but a mean of 1.5 second instar nymphs developed by day 5 on Bacui- 2 . Third instars nymphs developed 2 to 3 d later on Bacui-2 than on the other genotypes. The mean durations of each instar did not significantly differ, although the length varied from 1 to $2.33 \mathrm{~d}$ for the first instars, 1 to $4 \mathrm{~d}$ for the second instars, 100 to $7.33 \mathrm{~d}$ for the third instars, 4 to $7 \mathrm{~d}$ for the fourth instars, and 4.75 to $10.67 \mathrm{~d}$ for the fifth instars. Both the Cochran-MantelHaenszel statistic-2 and the Kruskal-Wallis probabilities were nonsignificant for the nonnormally distributed variables. The PASI was significantly $(\operatorname{Pr}>F=0.05)$ different among genotypes only for day 19 (Table 1; Fig. 2).

\section{Discussion and Conclusions}

The values for percentage feeding on days 1 and 5 were similar in rank to those previously reported (Bell and Stuart, 1990; Bell, 1992), although the value for 'Karamanlika' was higher in the present study and that for Y-167 was lower. At one day after infestation, absence of live nymphs could be due to 1 ) migration off of the plant because of antixenosis, although none were observed on the tape, 2) injury during transfer, or 3) antibiotic effects of feeding. Even if some nymphs were injured, one would expect that would occur equally among the pear genotypes, so relative differences would still be reliable indicators of relative resistance. The nymphs feeding as a percentage of live nymphs were higher, but genotypes were similar in rank when the percentage was computed on the basis of the original 20 nymphs. Therefore, nymphal feeding antixenosis is significant in 'Karamanlika', NY10352, and the two Bacui genotypes. In 
Table 2. Mean first day of occurrence and minimum duration of presence ${ }^{\mathrm{z}}$ (number of days) of each instar for each genotype and mean day of first adult eclosion.

\begin{tabular}{|c|c|c|c|c|c|c|c|c|c|c|c|c|}
\hline \multirow[b]{2}{*}{ Genotype } & \multirow[b]{2}{*}{$N$} & \multicolumn{2}{|c|}{ First instar } & \multicolumn{2}{|c|}{ Second instar } & \multicolumn{2}{|c|}{ Third instar } & \multicolumn{2}{|c|}{ Fourth instar } & \multicolumn{2}{|c|}{ Fifth instar } & \multirow{2}{*}{$\begin{array}{l}\text { Adult } \\
\text { Mean } \\
\text { first day }\end{array}$} \\
\hline & & $\begin{array}{l}\text { Mean } \\
\text { first day }\end{array}$ & $\begin{array}{c}\text { Mean } \\
\text { duration }^{\mathrm{y}}\end{array}$ & $\begin{array}{l}\text { Mean } \\
\text { first day }\end{array}$ & $\begin{array}{c}\text { Mean } \\
\text { duration }\end{array}$ & $\begin{array}{c}\text { Mean } \\
\text { first day }\end{array}$ & $\begin{array}{c}\text { Mean } \\
\text { duration }\end{array}$ & $\begin{array}{l}\text { Mean } \\
\text { first day }\end{array}$ & $\begin{array}{l}\text { Mean } \\
\text { duration }\end{array}$ & $\begin{array}{l}\text { Mean } \\
\text { first day }\end{array}$ & $\begin{array}{c}\text { Mean } \\
\text { duration }\end{array}$ & \\
\hline Bartlett & 3 & - & 2.33 & 5.00 & 4.00 & 4.67 & $7.33 \mathrm{a}^{\mathrm{x}}$ & 9.33 & $7.00 \mathrm{a}$ & $14.33 \mathrm{a}$ & $10.67 \mathrm{a}$ & $20.0 \pm 3.2 \mathrm{a}$ \\
\hline Y-167 & 4 & - & 1.00 & 5.00 & 1.00 & 5.00 & $4.00 \mathrm{a}$ & 10.00 & $4.00 \mathrm{a}$ & $14.50 \mathrm{a}$ & $4.75 \mathrm{a}$ & $17.0 \pm 1.2 \mathrm{a}$ \\
\hline NY10352 & 4 & - & 1.00 & 5.00 & 1.50 & 5.75 & $5.25 \mathrm{a}$ & 13.75 & $6.25 \mathrm{a}$ & $18.67 \mathrm{a}$ & $7.00 \mathrm{a}$ & $20.5 \pm 1.5 \mathrm{a}$ \\
\hline Bacui-1 & 4 & - & 1.00 & - & - & - & - & - & - & - & - & - \\
\hline Bacui-2 & 4 & - & 1.00 & 3.00 & 1.00 & 8.00 & $1.00 \mathrm{a}$ & - & - & - & - & - \\
\hline
\end{tabular}

${ }^{\mathrm{z}}$ Duration determined as the number of sampling dates on which each instars of each stadium were counted. Note that observations were made at 3 or $4 \mathrm{~d}$ intervals, so the exact duration could not be determined.

${ }^{y}$ Data were not distributed normally. Analyses by nonparametric analysis of variance (SAS PROC NPAR1WAY) and the Cochran-Haenszel statistic 2 (SAS PROC FREQ) indicated no statistically significant differences.

${ }^{x}$ Means followed by the same letter are not statistically different, according to Fisher's protected $t$ test at $P=0.05$ with Tukey's multiple comparison adjustment computed by SAS PROC MIXED (Littell et al.,1996).

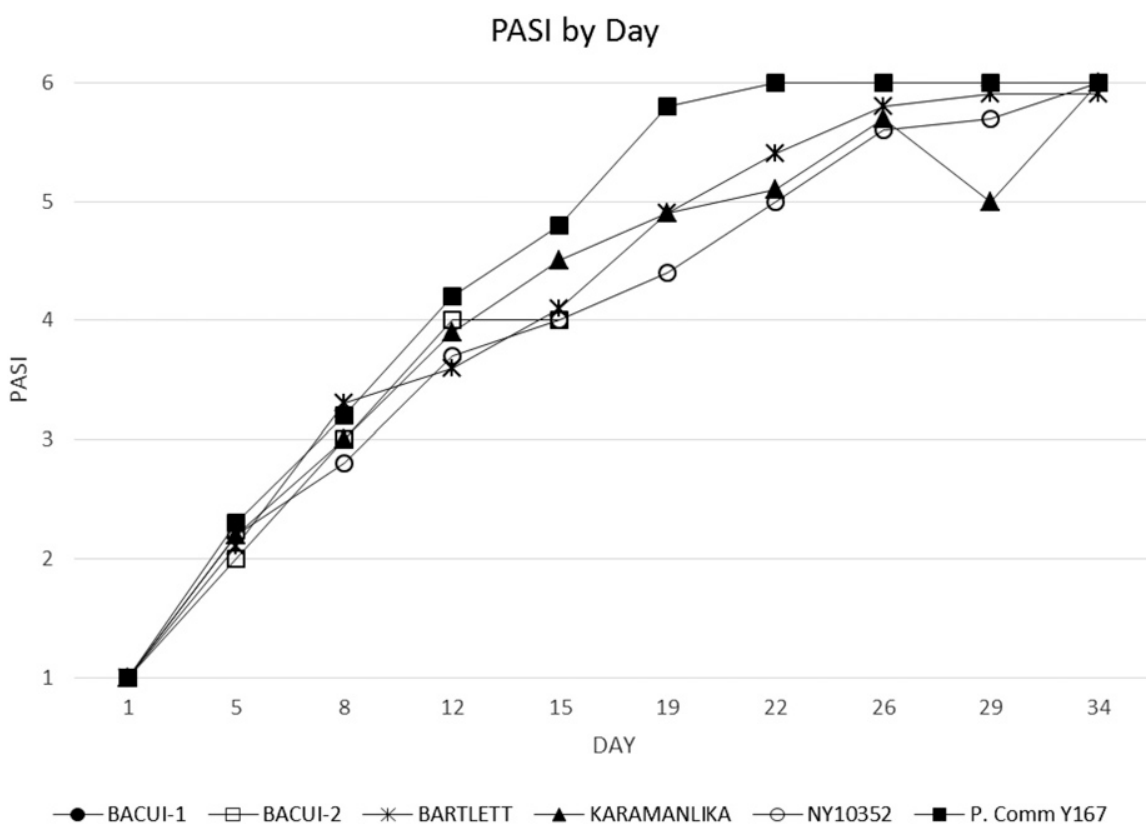

Fig. 2. Population age structure index (PASI) by day for six pear genotypes.

the case of the Bacui genotypes, the high degrees of antixenosis are not surprising, considering that these genotypes are intergeneric hybrids. The effects of antibiosis were evident starting one day after infestation, and those effects continued (Fig. 1). This result is similar to results by Puterka (1997), who reported significant antibiosis (i.e., mortality) four days after infestation, and similar to the results reported by Butt et al. (1989).

Antibiosis rapidly affected nymphs placed on the Bacui genotypes, again evidence that the intergeneric hybrids are not suitable hosts for pear psylla. For the remaining genotypes, the progression, that is the range of days these instar were observed, were similar through the third instar. Occurrence on 'Bartlett' and Y-167 of the fourth and fifth instars was similar, but was delayed for 'Karamanlika' and NY10352. Thus, there appears to be some delayed development exhibited in the latter instars, although the effect was not significant for mean adult eclosion on those genotypes resistant to nymphal feeding. However, in an earlier study (Butt et al., 1989), delayed development of nymphs feeding on NY10352 was somewhat more evident throughout all stadia in comparison with 'Bartlett'; the duration of occurrence was also longer in the previous study, in contrast to the shorter duration in the present study. The percentages of adults emerging were similar for the previous and the current study. The differences among the four genotypes with surviving psylla were not significant; however, there were large differences in the number of surviving psylla, indicating significant antibiosis. The development of few adults on 'Karamanlika' and NY10352 may indicate the presence of psylla genotypes with tolerance or resistance to the mechanisms of resistance, and the possibility of selection over time of the ability to some degree to overcome the host resistance (Puterka, 1997). The lack of adult development on these genotypes contrasts with results presented by Robert et al. (1999) who studied 'Katman', another East European landrace cultivar and NY10355, another P. ussuriensis $\times$ $P$. communis backcross hybrid closely related to NY10352. Pasqualini et al. (2006) also reported a lack of complete development on NY10353, another related hybrid.

Nymphal feeding antixenosis, evident soon after infestation, clearly is associated with mortality, similar to the conclusions of earlier studies (Butt et al., 1989; Nin et al., 2012; Puterka, 1997). Percentage feeding on day 1 essentially separated the genotypes into three groups, and groupings for percentage live nymphs on day 1 and mean number of adults were very similar. The effect could be due to reduced amount or duration of feeding, leading to starvation, or due to direct toxic compounds, such as phenolics and/or other phytochemicals, factors associated with the resistant genotypes. These could be constitutive or rapidly induced de novo by psylla feeding (Scutareanu et al., 1999). Short-term nymphal feeding assays are confirmed as a useful rapid initial test of resistance to pear psylla. The association is less evident for the relationship to delayed development, as evidenced by a lack of significant differences for the days of occurrence of each instar, the duration of each instar, and the PASIs for all but day 19. The four genotypes shown in this study to be resistant to nymphal feeding and exhibiting increased mortality have also been shown to be relatively resistant to oviposition (Bell, 1991), suggesting that the same mechanism affecting nymphal feeding and development also is responsible for ovipositional antixenosis, a trait that is associated with adult probing behavior (Horton and Krysan, 1990, 1991). 'Karamanlika', NY10352, Bacui-1 and Bacui-2 are identified as potentially useful germplasm for genetic improvement of pear for resistance to pear psylla.

\section{Literature Cited}

Bell, R.L. 1991. Ovipositional antixenosis-based host resistance to the pear psylla in Pyrus germplasm of East European origin. HortScience 26:710.

Bell, R.L. 1992. Additional East European Pyrus germplasm with resistance to pear psylla nymphal feeding. HortScience 27:412-413.

Bell, R.L. 2003. Resistance to pear psylla nymphal feeding of germplasm from Central Europe. Acta Hort. 622:343-345.

Bell, R.L. and G.L. Puterka. 2003. Modes of host plant resistance to pear psylla: A review. Acta Hort. 622:343-345.

Bell, R.L. and C.L. Stuart. 1990. Resistance in Eastern European Pyrus germplasm to pear psylla nymphal feeding. HortScience 25:789-791.

Berrada, S., T.X. Xguyen, J. Lemoine, J. Vanpoucke, and D. Fournier. 1995. Thirteen pear species and cultivars evaluated for resistance to Cacopsylla 
pyri (Homoptera: Psyllidae). Environ. Entomol. 24:1604-1607.

Braniste, N., V. Amzar, M. Radulescu, and D. Sugar. 1994. Resistance sources to psylla sp. Acta Hort. 367:54-63.

Briolini, G., A. Cappeli, L. Rivalta, and P. Rosati. 1988. Observations on Pyrus communis resistance to Psylla pyri. Acta Hort. 224:211-221.

Butt, B.A., L.C. Stuart, and R.L. Bell. 1988. Feeding behavior of pear psylla (Homoptera: Psyllidae) nymphs on susceptible and resistant Pyrus germplasm. J. Econ. Entomol. 81:13941397.

Butt, B.A., L.C. Stuart, and R.L. Bell. 1989 Feeding, longevity, and development of pear psylla (Homoptera:Psyllidae) nymphs on resistant and susceptible pear genotypes. J. Econ. Entomol. 82:458-461.

Follet, P.A., B.A. Croft, and P.H. Westigard. 1985. Regional resistance to insecticides in Psylla pyricola from pear orchards in Oregon. Can. Entomol. 117:565-573.

Harris, M.K. 1973. Host resistance to the pear psylla in a $P$. communis $\times P$. ussuriensis hybrid. Environ. Entomol. 2:883-887.

Harris, M.K. and R.C. Lamb. 1973. Resistance to the pear psylla in pears with Pyrus ussuriensis lineage. J. Amer. Soc. Hort. Sci. 98:378381.

Hibino, H., G.H. Kaloostian, and H. Schneider. 1971. Mycoplasma-like bodies in the pear psylla vector of pear decline. Virology 43:34-40.

Horton, D.R. and J.L. Krysan. 1990. Probing and oviposition-related activity of summerform pear psylla (Homoptera: Psyllidae) on host and non-host substrates. Environ. Entomol. 21:1319-1332.

Horton, D.R. and J.L. Krysan. 1991. Host acceptance behavior of pear psylla (Homoptera: Psyllidae) affected by plant species, host deprivation, habituation, and eggload. Ann. Entomol. Soc. Am. 84:612-627.
Littell, R.C., G.A. Milliken, W.W. Stroup, and R.D. Wolfinger. 1996. SAS system for mixed models. SAS Institute Inc., Cary, NC.

Nin, S., A. Ferri, P. Sacchetti, and E. Giordani. 2012. Pear resistance to psylla (Cacopsylla pyri L.). A review. Adv. Hort. Sci. 26:59-74.

Pasqualini, E., S. Civolani, S. Musacchi, V. Ancarani, L. Dondini, P. Robert, and P. Baronio. 2006. Cacopsylla pyri behaviour on new pear selections for host resistance programs. Bull. Insectology 59(1):27-37.

Pree, D.J., K.W. Archibald, K.W. Kerr, and K.J. Kole. 1990. Occurrence of pyrethroid resistance in pear psylla (Homoptera: Psyllidae) populations in southern Ontario. J. Econ. Entomol. 83:2159-2163.

Puterka, G.L. 1997. Intraspecific variation in pear psylla (Homoptera: Psyllidae) nymphal survival and development on resistant and susceptible pear. Environ. Entomol. 26:552-558.

Quamme, H.A. 1984. Observations of psylla resistance among several pear cultivars and species. Fruit Var. J. 38:34-36.

Quarta, R. and D. Puggioni. 1985. Survey on the variety susceptibility to pear psylla. Acta Hort. 159:77-86.

Robert, P., J. Chausset, and M. Le Lézec. 1999. Larval development of Cacopsylla pyri (L.) [Homoptera: Psyllidae] on two resistant Pyrus genotypes. IOBC WPRS Bull. 22 (10):89-91.

Robert, P., P. Guérif, J. Lemoine, and M. Le Lézec. 2004. Criblage de génotypes du Pyrus visà-vis de la résistance au psylle du poirier Cacopsylla pyri (L.). Cahiers Agricultures 13:349-354.

Robert, P., T. Raimbault, M. Le Lézec, and M.H. Simard. 2005. Resistance of some Pyrus communis cultivars and Pyrus hybrids to the pear psylla Cacopsylla pyri (Homoptera, Psyllidae). Acta Hort. 671:571-575.

SAS Institute, Inc. 2013. SAS 9.4. SAS Institute Inc., Cary, NC.
Saxton, A.M. 1998. A macro for converting mean separation output to letter groupings in Proc Mixed. In: Proceedings of the 23rd SAS Users Group International, SAS Institute, Cary, NC. pp. 1243-1246.

Scutareanu, P., Y. Ma, M. Claeys, R. Dommisse, and W. Sabelis. 1999. Induction of a p-cumarouyl trihydroxy triterpene acid in psylla-infested and mechanically damaged pear trees. J. Chem. Entomol. 25:2177-2191.

Shaltiel, L. and M. Coll. 2010. Reduction of pear psylla damage by the predatory bug Anthocoris nemoralis (Heteroptera: Anthocoridae): The importance of orchard colonization time and neighboring vegetation. Biocontrol Sci. Technol. 14:811-821

Shaltiel-Harpaz, L., V. Soroker, R. Kedoshim, R. Hason, T. Sokalsky, K. Hatib, I. Bar-Ya'akov, and D. Holland. 2014. Two pear accessions evaluated for susceptibility to pear psylla Cacopsylla bidens (ك̌ulc) in Israel. Pest Mgt. Sci. 70:234-239.

Singleton-Smith, J., J.F. Chang, and B.J.R. Philogene. 1978. Morphological differences between nymphal instars and descriptions of the antennal sensory structures of the nymphs and adults of Psylla pyricola Foerster (Homoptera: Psyllidae). Can. J. Zool. $56: 1576-1584$

van der Zwet, T., V. Cociu, J. Czarnecki, J. Nyeki, and J. Blazek. 1989. Collecting Pyrus germplasm in Romania, Poland, Hungary, and Czechoslovakia. HortScience 22:15-21.

van der Zwet, T., D. Stankovic, and B. Ristevski. 1987. Collecting Pyrus germplasm in Yugoslavia. HortScience 22:15-21.

Westigard, P.H., M.N. Westwood, and P.B. Lombard. 1970. Host preference and resistance of Pyrus species to the pear psylla, Psylla pyricola Föerster. J. Amer. Soc. Hort. Sci. 95: 34-36. 